\title{
Landscape transform and spatial metrics for mapping spatio-temporal land cover dynamics using Earth Observation datasets
}

\author{
Sudhir Kumar Singh, Prashant K. Srivastava, Szilárd Szabó, George P. \\ Petropoulos, Manika Gupta \& Tanvir Islam
}

To cite this article: Sudhir Kumar Singh, Prashant K. Srivastava, Szilárd Szabó, George P. Petropoulos, Manika Gupta \& Tanvir Islam (2015): Landscape transform and spatial metrics for mapping spatio-temporal land cover dynamics using Earth Observation datasets, Geocarto International, DOI: 10.1080/10106049.2015.1130084

To link to this article: http://dx.doi.org/10.1080/10106049.2015.1130084

Accepted author version posted online: 13

Dec 2015.

Submit your article to this journal $₫$

Щ Article views: 16

Q View related articles $\longleftarrow$

View Crossmark data $\nearrow$ 
Publisher: Taylor \& Francis

Journal: Geocarto International

DOI: http://dx.doi.org/10.1080/10106049.2015.1130084

\section{Landscape transform and spatial metrics for mapping spatio-temporal land cover dynamics using Earth Observation datasets}

Sudhir Kumar Singh ${ }^{\mathrm{a}}$, Prashant K. Srivastava ${ }^{\mathrm{b}, \mathrm{c}, \mathrm{d} *}$, Szilárd Szabó ${ }^{\mathrm{e}}$, George P. Petropoulos ${ }^{\mathrm{f}}$, Manika Gupta ${ }^{\mathrm{g}}$, Tanvir Islam ${ }^{\mathrm{h}, \mathrm{i}}$

${ }^{a} K$. Banerjee Centre of Atmospheric and Ocean Studies, IIDS, Nehru Science Centre, University of Allahabad, India

${ }^{b}$ NASA Goddard Space Flight Center, Greenbelt, Maryland, USA

${ }^{c}$ Earth System Science Interdisciplinary Center, University of Maryland, Maryland, USA

${ }^{d}$ Institute of Environment and Sustainable Development, Banaras Hindu University, Varanasi,

India

${ }^{\mathrm{e}}$ University of Debrecen, Department of Physical Geography and Geoinformatics, Debrecen, Hungary

${ }^{f}$ Department of Geography and Earth Sciences, University of Aberystwyth, Wales, UK

${ }^{g}$ Department of Ciyil Engineering, Indian Institute of Technology, New Delhi, India

${ }^{h}$ NOAA/NESDIS Center for Satellite Applications and Research, College Park, MD, USA

${ }^{i}$ Cooperative Institute for Research in the Atmosphere, Colorado State University, Fort Collins,

CO, USA

*Correspondence: prashant.k.srivastava@nasa.gov; prashant.just@gmail.com 


\begin{abstract}
Analysis of Earth Observation (EO) data, often combined with Geographical Information Systems (GIS), allows monitoring of land cover dynamics over different ecosystems, including protected or conservation sites. The aim of this study is to use contemporary technologies such as EO and GIS in synergy with fragmentation analysis, to quantify the changes in the landscape of the Rajaji National Park (RNP) during the period of 19 years (1990-2009). Several statistics such as Principal Component Analysis (PCA) and spatial metrics are used to understand the results. PCA analysis has produced two principal components (PC) and explained $84.1 \%$ of the total variance while the second component (PC2) has accounted for the $26.3 \%$ of the total variance calculated from the core area metrics, distance metrics and shape metrics. Our results suggested that notable changes happened in the RNP landscape, evidencing the requirement of taking appropriate measures to conserve this natural ecosystem.
\end{abstract}

Keywords: Protected Ecosystem; Remote Sensing; Landscape pattern; Fragmentation; Ecological metrics, Geographic Information System

\title{
1. INTRODUCTION
}

India is one of the 12 mega-biodiversity country of the world. The total protected area network in India includes as: 100 National Parks, 515 Wildlife Sanctuaries, 43 Conservation Reserves and four Community Reserves (http://envfor.nic.in/report/report.html). However, after industrial revolution in India, the rapid non planned development of infrastructure and population growth 
has intensified which caused a continuous and noticeable influence on natural resources of the country (Gadgil and Guha 1995). The overall population of country India is continuously increasing in last three decades, it has been noticed as 846,387,888 (1991), 1,028,737,436 (2001), 1,210,726,932 (2011) persons in Census of India datasets (censusindia.gov.in/). This high rise in number of persons has caused many adverse impacts on natural resources and wildlife. The changes that have taken place are especially important and intense, as society is becoming increasingly modernized and urbanized, while natural ecosystems are continuously deteriorated, over exploited or almost losing their original structure, forms and functions (Dai et al. 2014, Islam and Weil 2000, Pandey et al. 2012). This detrimental increase in human growth has resulted in a shrinkage of natural habitat (Venture 2005) as well as wildlife.

Land cover has constituted a key variable of the Earth's system that in general has shown a close correlation with human activities and the physical environment (Bell et al. 2005, Srivastava et al. 2010). Land cover mostly changes due to its interaction with physical, ecological, geomorphic and anthropogenic processes (Naveh 1987, Paudel et al. 2015). From all the above, the anthropogenic factor has emerged as a serious factor for change in landscape structure, pattern and dynamics (Naveh and Lieberman 1990, Petropoulos et al. 2015, Srivastava, Han, Ramirez, et al. 2012). Because of high anthropogenic pressure on natural and semi-natural habitats, conservation and sustainable practices for land cover has become a priority (De Groot 2006) of research community and other stakeholders. Hence, quantifying the temporal and spatial patterns of land use/land cover (LULC) change and its corresponding consequences (Singh et al. 2010, Singh et al. 2012) particularly over protected areas - is recognized as a highly significant topic (Fraser and Latifovic 2005) of research in recent period. Earth Observation (EO) technology is very well-suited for mapping and monitoring of habitats because of its synoptic repetitive coverage over the same area at various spatial and temporal scales, even datasets are available for inaccessible locations 
(Sanchez-Hernandez et al. 2007) at low cost compared to conventional methods of data collection. These EO datasets are available on geospatial platform, they can provide an effective set of tools for analysing and extracting spatial information to support decision making with more reliable and consistent way (Jankowski and Richard 1994, Srivastava, Gupta, et al. 2012, Srivastava, Mukherjee, et al. 2014).

A large number of landscape change studies in technical literature domain are available by employing different types EO datasets. The Landsat sensors have shown an excellent promise for synoptic and temporal analysis of the changes (Gupta and Srivastava 2010, Hansen and Loveland 2012) and provide images at high resolution. However, very rare studies are available for developing countries like India. The land cover change studies are very important to understand the exploitation patterns and assessment of area (Banerjee and Sriyastava 2014, Srivastava, Kiran, et al. 2012). If landscape changes occurred for prolonged period, it may eliminate species and disturb the ecosystem functioning and services (Martínez et al. 2009, Priess et al. 2007). Yet, most of them considered only forest to agricultural conversions (Singh et al. 2013).

From a biodiversity point of view fragmentation, loss and degradation of habitat are widely considered as the most important driving factors (Hanski 2005, Lindenmayer and Fischer 2006) and hence this is the current topic of research. The term fragmentation has been defined as simultaneous reduction of forest area and subdivision of large forest areas into smaller noncontiguous fragments (Laurance 2000, Midha and Mathur 2010). Forest fragmentation is a dynamic development that results in change in pattern of the habitats (Midha and Mathur 2010). The serious impact of fragmentation include loss of habitat, decreased connectivity between ecological entities, reduction in patch size, elevated distance between patches, and an abrupt increase in the edge at the expense of interior habitat (Midha and Mathur 2010). Causes of fragmentation and habitat loss can be linked to agriculture and infrastructure development, overexploitation of natural resources, pollution and invasive species (Semwal et al. 2005). At the 
landscape level, disturbance is related to patch structure, spatial arrangement, their size and duration (McGarigal and Marks 1995) and can be quantified using the spatial landscape metrics and metrics are the algorithms designed for quantifying landscape pattern depicting the spatial arrangement of land cover patches over a particular geographic area (Herold et al. 2003, McGarigal and Marks 1995, Remmel et al. 2002). The analysis of landscape level and class level metrics has provided a strong conceptual and theoretical basis for understanding landscape structure, function and change. These landscape and class level metrics can be used to evaluate the human impacts on natural cover types such as forest. In this context, the present study aimed to combine remote sensing and GIS techniques with the landscape transform concept with objectives such as: i) to characterize the dynamics of land cover change, ii) to assess and quantify the fragmentation pattern of Rajaji National Park (RNP). The results of this study provide the data and information for evidence-based decision-making for sustainable management of this ecologically and economically vital ecosystem.

\section{STUDY AREA}

The Rajaji National Park (RNP) is located in Shiwalik range of Himalaya of India and lies between coordinates $29^{\circ} 15^{\prime} \mathrm{N}$ to $30^{\circ} 31^{\prime} \mathrm{N}$ and $77^{\circ} 52^{\prime} \mathrm{E}$ to $78^{\circ} 22^{\prime} \mathrm{E}$ (Figure 1). Elevation of the area varies widely from 250 to $1100 \mathrm{~m}$ above mean sea level. This entire belt is natural home of Asian elephants (Elephas maximus). Besides, many other wild animals like tiger (Panthera tigris), leopard (Panthera pardus ), Sloth bear (Melursus ursinus ), Hyaena (Hyaena hyaena), etc. are also common in this region (Joshi 2009). The under-wood is consisting of flora Palash (Butea monosperma), Rohini (Malollotus philippinensis), Amaltas (Cassia fistula), Shisham (Dalbergia sissoo), Sal (Shorea robusta), Arjun (Terminalia arjuna), Khair (Acacia catechu), Sandan (Ougeinia Oojeinensis), Chamaror (Ehretia laevis), Kachnar (Bauhienia variegata), etc (http://www.rajajinationalpark.co.in/8.\%20Wild\%20life\%20-\%20flora.htm) in RNP. 
In 1983, RNP has been created by amalgamation of three sanctuaries Rajaji sanctuary (estd. 1948), Motichur sanctuary (estd. 1964) and Chilla sanctuary (estd. 1977) and considered as national park to protect the Asian elephant's habitat and currently covering an area of $\sim 820.42 \mathrm{~km}^{2}$. It has been designated as a reserved area for both "Elephant and Tiger" by the Ministry of Environment and Forests, Government of India (MoES, GOI), with the sole aim for maintaining the viable wildlife population. It comes under International Union for Conservation of Nature and Natural Resources (IUCN) Category II by the World Conservation Union. There are three main seasons at RNP as winter (December to February), summer (March to June), monsoon (July to September) and autumn (October to November). The average range of temperature during the winter is $20-15^{\circ} \mathrm{C}$ (November to February), whereas during the summer (May to June) temperature reaches up to 32$40^{\circ} \mathrm{C}$. The average annual rainfall ranges from $1200-1500 \mathrm{~mm}$ with very high humidity. Mostly the rainfall received from the South West monsoon season.

\section{Figure 1 Geographical location of the study area}

\section{DATASETS}

In this study we used the Landsat datasets. Total eight Survey of India (SOI) topographical-sheets number as follows: $(53-\mathrm{F} / 15, \mathrm{~F} / 16, \mathrm{G} / 13, \mathrm{I} / 7, \mathrm{~J} / 4, \mathrm{~J} / 8, \mathrm{~K} / 1$, and $\mathrm{K} / 5)$ of scale 1:50,000 were used for the Geometric correction of satellite images and creation of baseline datasets. Landsat images were obtained from the United State Geological Survey (USGS) archive (http://glovis.usgs.gov/) at no cost. All satellite images were acquired in different years during the studied period but around of the same month and season to minimize any seasonal and phenological variations (Lillesand et al. 2004) in land cover.

\section{METHODOLOGY}

LULC estimation of studied region was carried out using ENVI (v. 5.0, ITT Visual Solutions) and ArcGIS (v. 10.1, ESRI) software platforms. Further, the output product of ENVI and ArcGIS was 
used in FRAGSTAT (v. 3.3) to compute ecological metrics. An overview of the methodology implemented in study is depicted in Figure 2. A description of the steps taken in evaluating the land cover spatio-temporal dynamics at RNP during the studied period is discussed in following subsections.

\subsection{Pre-processing}

The Landsat images were downloaded from United States Geological Survey (USGS) portal (http://www.usgs.gov/) and details are given in (Table1). Further, imported into ENVI software and converted to radiance values (Irons, 2011) and subsequently layer stacking were performed except for the thermal infrared band (i.e. band 6). Image atmospheric calibration was conducted by adopting the procedure as documented by USGS. After layer stacking an empirical line normalisation to all images were implemented using the Landsat 1990 image as a base (Guide 2008). In order to analyse temporal satellite imagery of same area needs to be stacked layers and it must be spatially co-registered in the common spatial frame reference (Schmidt and Glaesser 1998), hence an image to image co-registration has been performed in ENVI to a common WGS84 ellipsoid projection.

Table 1 Description of satellite datasets used in this study

Figure 2 Flow chart depicting the methodology applied in this study

\subsection{Classification of satellite images}

In the next step, LULC maps were derived from the Landsat images by applying the Maximum Likelihood Classifier (MLC) based approach used by many researchers (Foody et al. 1992, Srivastava, Mehta, et al. 2014, Strahler 1980). MLC has not only considered the mean or average values in assigning classification, but also the variability of brightness values in each class (Banerjee and Srivastava 2013). It is based on Bayes' theorem and the equation (1) used in MLC classification is expressed as (Guide 2008): 
$D=\ln \left(a_{c}\right)-\left[0.5 \ln \left(\left|\operatorname{cov}_{c}\right|\right)\right]-\left[0.5\left(\mathbf{X}-\mathbf{M}_{c}\right)^{\mathrm{T}}\left(\operatorname{cov}_{c}^{-1}\right)\left(\mathbf{X}-\mathbf{M}_{c}\right)\right]$

where, $\mathrm{D}$ is weighted distance; $\mathrm{c}$ is a particular class; $\mathbf{X}$ is the measurement vector of the particular pixel; $\mathbf{M}_{\mathrm{C}}$ is the mean vector of the sample of class; $\mathrm{a}_{\mathrm{C}}$ is percent probability that any particular pixel is a member of class c; (Defaults to 1.0 ); $\operatorname{cov}_{\mathrm{c}}$ is the covariance matrix of the pixels in the sample of class $\mathrm{c}$; $\left|\operatorname{cov}_{\mathrm{c}}\right|$ is determinant of $\operatorname{cov}_{\mathrm{c}}$; $\operatorname{cov}_{\mathrm{c}}-1$ is inverse of $\operatorname{cov}_{\mathrm{c}}, \ln$ is natural logarithm function; $\mathrm{T}=$ transposition function.

For MLC, first the classification key was formulated, consisting of the classes "built-up", "forest open", "forest mixed", "forest dense", "crop land" and "water bodies" then the training pixels representative of each class were collected from the homogeneous regions. Approximately 30 pixels of each class included in our classification scheme (a total of approximately 180 pixels) were identified as training data. By using the collected training points, the MLC was parameterized and implemented on all pre-processed images. Band 2, 3, and 4 are used with a single probability threshold value of zero for all the LULC classification using the MLC.

\subsection{Ecological metrics analysis}

The relevant landscape metrics such as area, perimeter, core area, shape and fragmentation at patch and class level were used in this study. The FRAGSTATS 3.3 developed by McGarigal and Marks, 1995 is used in this study for estimation of all the spatial statistics. This software platform is widely implemented nowadays by decision maker, ecologists, wildlife experts and statistician to analyze, characterize and describe the landscape fragmentation (Çakir et al. 2008, Ricketts 2001). The advantage of FRAGSTATS is that the calculations are applied in a GIS environment and thus can be used with satellite images (McGarigal et al. 2002, Rempel et al. 1999, Singh et al. 2014). Area has provided information to explore the proportion of LULC categories and perimeterindices that helped to understand the role of the edges. The longer the edge of a patch to a given 
area, the more complex the shape, it means patch stability can be judged from ecological perspective. The size of grid attributes is $30 \mathrm{~m}$ with the input file type landscape. The analysis type is used as standard with 8 cell patch neighbours rule. Edge depth was also considered with a buffer zone of $100 \mathrm{~m}$, to calculate the inner undisturbed area, core area of the patches. Furthermore, distance between the patches belonging to the same LULC class and the fragmentation was determined, too. In the analysis, the following landscape metrics were involved:

- Area and perimeter metrics: area (AREA, ha), perimeter (PERIM, m), and their summarized or averaged quantities (sum of patch areas by LULC classes; mean of patch areas summarized by LULC classes, AREA_MN; mean of edge lengths, PERIM_MN); total edge (TE, m); patch density (ratio of number of patches and the area of investigated, $\mathrm{PD}$, per unit per ha), edge density (ED, m per hectare)and largest patch index (LPI) (ratio of largest patch the area of investigated area); percentage of like adjacencies (PLAND, \%) as proportion of a given class type related to the total area.

- Core area metrics: core area (CORE, ha), core area index (core areas expressed as the function of the whole area of the LULC class, CAI, \%) and the disjunct core area density (ratio of the number of disjunct core areas within a specified distance and the whole area, DCAD, number per $\mathrm{km}^{2}$ ).

- Shape metrics: related circumscribing circle in patch and in class level (CIRCLE and CIRCLE_MN, respectively; ratio of the area of a given patch and the area of the smallest circumscribing circle, CIRCLE, between 0-1).

Distance metrics: Nearest neighbor Euclidean distance between patches belonging to the same LULC class in patch and class level (ENN and ENN_MN, respectively, m).

- Fragmentation metrics: effective mesh size (MESH, ha) is in high correlation with landscape division which expresses the probability that two randomly placed in the 
landscape are in the same patch; mesh size is the area of equal sized patches that necessary to be divide the whole area to reach the above probability value (Jaeger, 2000).

\subsection{Statistical evaluation}

A statistical evaluation was carried out to reveal the changes of the landscape between the different dates. We conducted a Principal Component Analysis (PCA) (based on the correlation matrices) with Varimax rotation to reveal the differences in the multivariate space (Srivastava, Han, Gupta, et al. 2012). It is a multivariate dimension reducing technique that makes possible to study several correlating variables in the same time (Singh et al. 2015). The spatial metrics such as PLAND, PD, ED, CIRCLE, DCAD, MESH and ENN metrics were used in the analysis. Biplot diagram showed the correlation structure of the variables; besides, indicated the changes based on the involved metrics (Livingstone 2009).

\subsection{Accuracy Assessment}

The accuracy of the different thematic maps produced from the classifiers, accuracy assessment was performed based on the computation of the error matrix statistics (Congalton and Green, 1999). As a result, the overall accuracy (OA), user's accuracy (UA), producer's accuracy (PA) and the kappa coefficient (Kc) were computed, as follows (Congalton and Green 2008):

$$
\begin{aligned}
& \mathrm{OA}=\frac{1}{\mathrm{~N}} \sum_{r=1}^{r} n_{i i v},(7), \quad P A=\frac{n_{i i}}{n_{\text {icol }}}, \quad(8), \quad U A=\frac{n_{i i}}{n_{\text {irow }}} \\
& K_{c}=N \sum_{i=1}^{r} n_{i i}-\sum_{i=1}^{r} \frac{n_{\text {icol }} n_{\text {irow }}}{N^{2}}-\sum_{i=1}^{r} n_{\text {icol }} n_{\text {irow }},(10)
\end{aligned}
$$

where $n_{i i}$ is the number of pixels correctly classified in a category; $N$ is the total number of pixels in the confusion matrix; $r$ is the number of rows; and $n_{\text {icol }}$ and $n_{\text {irow }}$ are the column (reference data) and row (predicted classes) total, respectively. 
In computing the above statistic metrics, approximately 30 GPS reference points/ground-truth points (i.e. pixels) from each class were taken from the study area for the accuracy estimation of the classified images. This information was obtained from field visits and previous studies that had been conducted in the area. Validation points were generally selected based on a random distribution in homogeneous regions and away from the locations where the training points had been collected, ensuring non-overlap of pixels between the training data and validation sites.

\section{RESULTS AND DISCUSSION}

\subsection{Accuracy of classified images}

The accuracy assessment results of the classified maps are summarized in Table 2 . On the basis of the OA, it can be seen that the highest overall classification accuracy was achieved for the year 2009 image $(82.05 \%)$ followed by that of $1990(77.78 \%)$ and of $2000(75.00 \%)$. The low classification accuracies might be related to the image acquisition dates. Mixed forest/deciduous forest can show quite different dynamics between the years (dropping of leaves is rather related to the climate than the calendar date). In 2009, the least performance of cropland can be attributed to mixed pixel response (Agro-forestry system). Similarly lower performances for those land cover class was also reported for 2000. The 1990 image classification performance was slightly better and can be linked to less cropland area and dense forest system compared to 2000. For the built-up area, open and mixed forest classes a PA of $>75 \%$ was obtained, suggesting that all of the collected validation samples also belonged in the same class as more number of times. For the same classes, UA was also reported in range $75-100 \%$ indicating that all of the points classified as built-up area, open and mixed forest classes could be expected to be the same area when a field survey is performed. The classification of the cropland, dense forest and water bodies' classes indicate a lower PA and UA than the other classes can be attributed to closed resemblance of dense forest with mixed forest and hence complicated the classification procedure. On the other 
hand, poor classification accuracy of water bodies and cropland can be related to the encroachment of forest canopies over the water body. The low performance of forest class may also be attributed to incapability of classifier to separate the three forest type that is open forest and mixed forest from the dense forest class.

\section{Table 2 Classification Accuracy of the satellite images}

\subsection{Spatial changes in LULC}

The classification maps produced from the implementation of the MLC are illustrated in Figure 3. The classes created and the area under the class provides an insight to the composition of the total area. Based on the results of the classification, it is possible to conclude up to a certain extent that the changes that occurred in the area. The analysis of result of water body showed overall change in area from 83.60 to $87.59 \mathrm{~km}^{2}$ from 1990 to 2000 and after this increment, in the year 2009 the area further decreased to $85.47 \mathrm{~km}^{2}$. The analysis of result of built-up area showed an increase in area from $6.50 \mathrm{~km}^{2}$ in 1990 to $7.85 \mathrm{~km}^{2}$ in 2000 and further, it also indicate an increasing trend up to $9.35 \mathrm{~km}^{2}$ in 2009 , this increase in the built-up area may be attributed to rise in human population in this region and dense forest area showed nominal decrease in area from $568.19 \mathrm{~km}^{2}$ in 1990 to $562.18 \mathrm{~km}^{2}$ in 2000 , which further, showed slight declined to $550.17 \mathrm{~km}^{2}$ in 2009 . This continuous declining trend of dense forest area may be because of developmental activities that have occurred in this region. Open forest has the area $54.44 \mathrm{~km}^{2}$ to $35.74 \mathrm{~km}^{2}$ in 1990 to 2000 and increased up to $66.02 \mathrm{~km}^{2}$ in 2009 . However, there is small change in area of mixed forest which increased from $153.95 \mathrm{~km}^{2}$ in 1990 to $175.03 \mathrm{~km}^{2}$ in 2000 and then decreased to $155.24 \mathrm{~km}^{2}$ in 2009. The main reason behind these changes can be attributed to rise in human population and encroachment forest land by local people who use this area's forest resources (fuel wood, timber, non timber forest products and fodder) or possibly it may be due to large demand of natural resources for the main industrial area of the state (State Infrastructure and Industrial Development Corporation of Uttarakhand Limited (SIDCUL) at district Hardiwar, Uttrakhand) as a raw 
material. The SIDCUL is found to be associated with rapid expansion of developmental activities near to the forest area and it requires natural resources like land, water and forest wood as a raw material. The crop land area decreases from $7.77 \mathrm{~km}^{2}$ in 1990 to $6.29 \mathrm{~km}^{2}$ in 2000 , whereas in 2009, it declined up to $6.16 \mathrm{~km}^{2}$ (Table 3). Around the RNP, during years (2001-2004), over 900 cases of crop raiding by elephants were recorded which occurred due to illegal encroachment of the park area by the local people. Figure 4 shows the overall change in the study area during the periods 1990-2000 and 2000-2009.

Table 3 Area of different land use classes in $\mathrm{km}^{2}$ for year 1990-2000-2009

Figure 3 Unclassified and classified satellite images of year 1990,2000 and 2009 respectively Figure 4 Change detection maps of period of 1990-2000 and 2000-2009.

\subsection{Fragmentation analysis}

The analysis of results showed that forests is a dominant land cover, while built-up area and crop land have only smaller proportion in the investigation period (Table 4 ) in the study area. Class of dense forest had the largest proportion, but at the same time it was consisted of the largest number of patches, too; consequently, its level of fragmentation was not far-gone due to its large area (MESH was between 902-1886 ha, which was the largest among all classes). An important change was that in 2009, MESH has decreased to the half of the area of 2000. For mixed forest, the proportion was between 6-7\% related to the whole area, but the average patch size was the largest in each year (more than 1000 ha, i.e. twice the average size of other categories). Also, LPI was the highest for this class, too; largest patch has covered 6-7\% of the class area. Open forest had smaller proportion $(\sim 2 \%)$ in a spatially dispersed pattern and were rather fragmented (see Table 3, MESH). Crop land relevance was very low, and also, their average patch size was the smallest; furthermore, their appearance in the landscape was dispersed. 
PCA has resulted into two principal components (PC) and explained $84.1 \%$ of the total variance. The first component (PC1) accounted for the $57.8 \%$ of the total variance and correlated with the PLAND MESH and PD (i.e. metrics indicating fragmentation). PC2 accounted for the $26.3 \%$ of the total variance and contrasted the DCAD, ENN and CIRCLE, while the ED correlated with both the PCs. Class metrics indicated a large overlap among the dates in the ordination space according to the convex hulls (Figure 5). All symbols of the LULC classes were found in the same section of the diagram and can be discriminated well with the help of the involved landscape metrics. Generally, the changes were slight. Largest changes were obseryed in case of mixed forest and dense forest classes along the variables correlating with PC2; i.e. the edge density and the number of disjunct core areas decreased while the nearest distance increased. Crop lands and open forests gained changes along the variables of PC1: there was an increase in their area from 1990 to 2009, consequently, the MESH also increased with the patch density. As it can be waited, water bodies changed the smallest. Furthermore, only in case of built up areas can be identified a trend.

There was overall loss of forest area means loss of dense forest, and open forest which suggest that this have been occurred due to population pressure, expansion of city area or other small and large scale development activities. These activities may be responsible for this loss, further, proved by the increase in built-up core area from 6.51 to $7.86 \mathrm{~km}^{2}$ in $1990-2000$ and 7.86 to $9.28 \mathrm{~km}^{2}$ in 2000-2009 respectively. This increase in built-up area has occurred on forest land of national park. These changes in MPS are further suggesting that the forest was more fragmented in 1990 than in 2000 and again it was more fragmented in 2009. Indeed, between year 1990 to 2000 period natural condition or human activities may have less impact on forest landscape and thus fragmentation was less in 2000. The birth of Uttaranchal as separate state came in existence in year 2000, hence many new development activities are witnessed in this region. But during the last two decades enhancement of traffic and rise in frequency of movement on national highways (NH5), train 
traffic on Haridwar - Dehradun railway track, rapid construction of new motor roads (Joshi and Singh 2010). From year 2000 to 2009 either human pressure or a natural condition has played a major role in the decrease of MPS which needs to be further examined. Large-scale habitat loss and human encroachment into the deeper forest regime are responsible for many changes in the park (Joshi and Singh 2010). One study reported that just one decade back elephant movement in this track was very common as this forest comprises of rich fodder and perennial water sources. Nevertheless, slowly their movement has been restricted in this part primarily due to increasing rate of human induced activities mainly inside the deeper forest regime, ongoing developmental activities, wildfires and shrinking of perennial water sources (Joshi 2009).

Indeed, to our knowledge, from 2002 onwards rapid expansion of developmental activities nearer to the forest area has caused obstruction in frequent movement of elephants besides other wildlife in adjoining forest beats. Tiger movement was frequently recorded before 2002 but after that tiger movement in these forest tracks has got obstructed. As a result of establishment of more than a dozen of industries, demand for water has been increasing and to meet the rising demand of water, ground water is being extracted by various stakeholder, industries and that has caused the major impact on ground water of adjacent areas.

Table 4 Class level landscape metrics of the LULC classes by dates (MN: mean of patch level metrics)

Figure 5 Biplot diagram of the PCA conducted with landscape metrics of the three dates (BU: built-in; CL: crop land; DF: dense forest; MF: mixed forest; OF: open forest; WB: water body; ---: group of LULC classes; +: 1990; $\square$ : 2000;•: 2009; Italic style green letters: landscape metrics)

6. Suggestion for improving the classification accuracy and reliability of landscape metrics 
The poor classification accuracies in image classification can be related to image acquisition dates as well as inadequacy in the architecture of classifier (Islam, Srivastava, et al. 2014) and error ground truths measurements. Further, for supervised classification techniques, some low performance can be related to human error in selecting the true pixels for training. Satellite image classification accuracy can be improved by using advanced algorithms such as support vector machine (SVM) (Islam et al. 2012), relevance vector machine (RVM) (Demir and Ertürk 2007), artificial neural network (ANN) (Heermann and Khazenie 1992), random forest algorithm (Gislason et al. 2006, Islam, Rico-Ramirez, et al. 2014) etc. However, applying these techniques to classify satellite data requires more expertise than MLC which is an easier technique to implement. Further, Shao and Wu (2008) derived an index called Relatiye Error of Area (REA) from the error matrix and demonstrated that the actual accuracy of areal estimates of LULC types is highly correlated with REA, but not consistently with UA, PA, or OA. In addition, they also mentioned that some landscape metrics (e.g., mean patch size and patch density) are more sensitive to classification accuracy than others. Therefore utilization of sophisticated classifiers can improve the performances of landscape metrics. As suggested by Shao and Wu in (2008), the role of different forest types could be also act as influencing factor in lowering down the classification accuracies as vegetation has different spectral responses in different seasons for e.g. leaf-on (Spring) and leaf-off (Autumn) are two distinct seasons which influence satellite image accuracies especially in built up area monitoring as it cover the surfaces. Discrepancies in the timing, spatial resolution and interval of remote sensing images may also result in major uncertainties in comparing different landscapes or detecting changes of the same landscape (Shao and $\mathrm{Wu} 2008$ ).

\section{Conclusions}


The relevance of this study lies in assessing the applied approaches and methods in providing data for evidence-based decision-making. The importance of land use/cover pattern using class level metric analysis is to assess the transformation types which affect the spatial pattern of the landscape. The diversity of metrics available and the complexity of habitat loss and fragmentation effects make it difficult to choose an appropriate metric or suite of metrics for a particular situation. Results from this study unveil the degree of land use change, diversity and fragmentation patterns occurred during the periods under study, which indicates that notable changes have taken place in the studied area. Landscape metric and landseape transformation analysis showed that over the time spatial configuration and composition of the landscape has changed drastically, which leads to the degradation of the forest area. The landscape metric analysis showed that from 1990 to 2000 the fragmentation of landscape was slightly low, it may be attributed to good natural and climate condition while, from the year 2000 to 2009 indicates that could be due to more human induced disturbance which have increased over the time. The results of this study will be useful to the forest conservation officers/forest manager, wild life conservators, environmentalist, research scientist and policy makers. Our future scope of the work will be to include other metrics such as contagion, juxtaposition, evenness and patchiness for the fragmentation analysis and evidence-based decision making.

\section{ACKNOWLEDGMENTS}

This research works is supported by K. Banerjee Centre of Atmospheric and Ocean Studies, IIDS, Nehru Science Centre, University of Allahabad, Allahabad, India. Authors also thank USGS (http://www.usgs.gov/pubprod/aerial.html\#satellite) for providing the Landsat satellite datasets.

\section{REFERENCES}

Banerjee R, Srivastava PK. 2014. Remote Sensing Based Identification of Painted Rock Shelter Sites: Appraisal Using Advanced Wide Field Sensor, Neural Network and Field Observations. In: 
Remote Sensing Applications in Environmental Research. Springer International Publishing. p. 195-212.

Banerjee R, Srivastava PK. 2013. Reconstruction of contested landscape: Detecting land cover transformation hosting cultural heritage sites from Central India using remote sensing. Land Use Policy.34:193-203.

Bell M, Walker MJ, Walker MJC. 2005. Late Quaternary environmental change: physical and human perspectives: Pearson Education.

Çakir G, Sivrikaya F, Keleş S. 2008. Forest cover change and fragmentation using Landsat data in Maçka State Forest Enterprise in Turkey. Environmental monitoring and assessment.137:51-66. Congalton RG, Green K. 2008. Assessing the accuracy of remotely sensed data: principles and practices: CRC press.

Dai Q, Han D, Rico Ramirez MA, Srivastava PK. 2014. Multivariate Distributed Ensemble Generator: A new scheme for ensemble radar precipitation estimation over temperate maritime climate. Journal of Hydrology.511:17-27.

De Groot R. 2006. Function-analysis and valuation as a tool to assess land use conflicts in planning for sustainable, multi-functional landscapes. Landscape and urban planning.75:175-186. Demir B, Ertürk S. 2007. Hyperspectral image classification using relevance vector machines. Geoscience and Remote Sensing Letters, IEEE.4:586-590.

Foody GM, Campbell N, Trodd N, Wood T. 1992. Derivation and applications of probabilistic measures of class membership from the maximum-likelihood classification. Photogrammetric Engineering and Remote Sensing.58:1335-1341.

Fraser R, Latifovic R. 2005. Mapping insect-induced tree defoliation and mortality using coarse spatial resolution satellite imagery. International Journal of Remote Sensing.26:193-200.

Gadgil M, Guha R. 1995. Ecology and equity: The use and abuse of nature in contemporary India: Psychology Press. 
Gislason PO, Benediktsson JA, Sveinsson JR. 2006. Random forests for land cover classification. Pattern Recognition Letters.27:294-300.

Guide EUs. 2008. ENVI on-line software user's manual. ITT Visual Information Solutions.

Gupta M, Srivastava PK. 2010. Integrating GIS and remote sensing for identification of groundwater potential zones in the hilly terrain of Pavagarh, Gujarat, India. Water International.35:233-245.

Hansen MC, Loveland TR. 2012. A review of large area monitoring of land cover change using Landsat data. Remote Sensing of Environment.122:66-74.

Hanski I. 2005. Landscape fragmentation, biodiversity loss and the societal response. EMBO reports.6:388.

Heermann PD, Khazenie N. 1992. Classification of multispectral remote sensing data using a back-propagation neural network. Geoscience and Remote Sensing, IEEE Transactions on.30:8188.

Herold M, Liu X, Clarke KC. 2003. Spatial metrics and image texture for mapping urban land use. Photogrammetric Engineering and Remote Sensing.69:991-1002.

Islam K, Weil R. 2000. Land use effects on soil quality in a tropical forest ecosystem of Bangladesh. Agriculture, ecosystems \& environment.79:9-16.

Islam T, Rico-RamirezMA, Han D, Srivastava PK. 2012. Artificial intelligence techniques for clutter identification with polarimetric radar signatures. Atmospheric Research.109:95-113. Islam T, Rico-Ramirez MA, Srivastava PK, Dai Q. 2014. Non-parametric rain/no rain screening method for satellite-borne passive microwave radiometers at $19-85 \mathrm{GHz}$ channels with the Random Forests algorithm. International Journal of Remote Sensing.35:3254-3267.

Islam T, Srivastava PK, Gupta M, Zhu X, Mukherjee S. 2014. Computational Intelligence Techniques in Earth and Environmental Sciences: Springer Netherlands. ISBN 978-94-017-86423. 
Jankowski P, Richard L. 1994. Integration of GIS-based suitability analysis and multicriteria evaluation in a spatial decision support system for route selection. Environment and Planning B.21:323-323.

Joshi R. 2009. Asian elephant's (Elephas maximus) behaviour in the Rajaji National Park, NorthWest India: eight years with Asian elephants. Nature and Science.7:49-77.

Joshi R, Singh R. 2010. Conservation Science.

Laurance WF. 2000. Do edge effects occur over large spatial scales? Trends in Ecology \& Evolution.15:134-135.

Lillesand TM, Kiefer RW, Chipman JW. 2004. Remote sensing and image interpretation: John Wiley \& Sons Ltd.

Lindenmayer D, Fischer J. 2006. Habitat fragmentation and landscape change: an ecological and conservation synthesis: Island Pr.

Livingstone DJ. 2009. A practical guide to scientific data analysis: John Wiley \& Sons.

Martínez ML, Pérez-Maqueo O, Vázquez G, Castillo-Campos G, García-Franco J, Mehltreter K, Equihua M, Landgrave R. 2009. Effects of land use change on biodiversity and ecosystem services in tropical montane cloud forests of Mexico. Forest Ecology and Management.258:1856-1863.

McGarigal K, Cushman SA, Neel MC, Ene E. 2002. FRAGSTATS: spatial pattern analysis program for categorical maps.

McGarigal K, Marks BJ. 1995. Spatial pattern analysis program for quantifying landscape structure. Gen Tech Rep PNW-GTR-351 US Department of Agriculture, Forest Service, Pacific Northwest Research Station.

Midha N, Mathur PK. 2010. Assessment of forest fragmentation in the conservation priority Dudhwa landscape, India using FRAGSTATS computed class level metrics. Journal of the Indian Society of Remote Sensing. 2010/09/01;38:487-500. 
Naveh Z. 1987. Biocybernetic and thermodynamic perspectives of landscape functions and land use patterns. Landscape Ecology.1:75-83.

Naveh Z, Lieberman AS. 1990. Landscape ecology: theory and application. Landscape ecology: theory and application.

Pandey PC, Sharma LK, Nathawat MS. 2012. Geospatial strategy for sustainable management of municipal solid waste for growing urban environment. Environmental monitoring and assessment.184:2419-2431.

Paudel D, Thakur JK, Singh SK, Srivastava PK. 2015. Soil characterization based on land cover heterogeneity over a tropical landscape: an integrated approach using earth observation data-sets. Geocarto International.30:218-241.

Petropoulos GP, Kalivas DP, Georgopoulou IA, Srivastava PK. 2015. Urban vegetation cover extraction from hyperspectral imagery and geographic information system spatial analysis techniques: case of Athens, Greece. Journal of Applied Remote Sensing.9:096088-096088. Priess J, Mimler M, Klein AM, Schwarze S, Tscharntke T, Steffan-Dewenter I. 2007. Linking deforestation scenarios to pollination services and economic returns in coffee agroforestry systems. Ecological Applications.17:407-417.

Remmel TK, Csillag F, Mitchell SW, Boots B. 2002. Empirical distributions of landscape pattern indices as functions of classified image composition and spatial structure. Proc "Geospatial theory, processing and applications"'CD-ROM, Canadian Institute of Geomatics, Ottawa.

Rempel RS, Carr A, Elkie PC. 1999. Patch analyst user's manual: a tool for quantifying landscape structure: Ontario Ministry of Natural Resources, Boreal Science, Northwest Science \& Technology.

Ricketts TH. 2001. The matrix matters: effective isolation in fragmented landscapes. The American Naturalist.158:87-99. 
Sanchez-Hernandez C, Boyd DS, Foody GM. 2007. Mapping specific habitats from remotely sensed imagery: support vector machine and support vector data description based classification of coastal saltmarsh habitats. Ecological Informatics.2:83-88.

Schmidt H, Glaesser C. 1998. Multitemporal analysis of satellite data and their use in the monitoring of the environmental impacts of open cast lignite mining areas in Eastern Germany. International Journal of Remote Sensing.19:2245-2260.

Semwal RL, Forests WWFfN--I, Programme BC. 2005. The Terai Arc Landscape in India: Securing Protected Areas in the Face of Global Change: Forests \& Biodiversity Conservation Programme, World Wide Fund for Nature--India, New Delhi for Regional Protected Area Programme, Asia, IUCN--The World Conservation Union, Hanoi, Vietnam and Keidanren Nature Conservation Fund.

Shao G, Wu J. 2008. On the accuracy of landscape pattern analysis using remote sensing data. Landscape Ecology.23:505-511.

Singh S, Pandey A, Singh D. 2014. Land Use Fragmentation analysis using remote sensing and Fragstats: P. K. Srivastava et al. (eds.), Remote Sensing Applications in Environmental Research, Society of Earth Scientists Series, pp 151-176. Springer International Publishing Switzerland 2014. ISBN: 978-3-319-05905-1.

Singh S, Srivastava P, Pandey A. 2013. Fluoride contamination mapping of groundwater in Northern India integrated with geochemical indicators and GIS. Water Science \& Technology: Water Supply.

Singh SK, Srivastava PK, Singh D, Han D, Gautam SK, Pandey A. 2015. Modeling groundwater quality over a humid subtropical region using numerical indices, earth observation datasets, and X-ray diffraction technique: a case study of Allahabad district, India. Environmental Geochemistry and Health.37:157-180. 
Srivastava PK, Gupta M, Mukherjee S. 2012. Mapping spatial distribution of pollutants in groundwater of a tropical area of India using remote sensing and GIS. Applied Geomatics.4:21-32. Srivastava PK, Han D, Gupta M, Mukherjee S. 2012. Integrated framework for monitoring groundwater pollution using a geographical information system and multivariate analysis. Hydrological Sciences Journal.57:1453-1472.

Srivastava PK, Han D, Ramirez MR, Bray M, Islam T. 2012. Selection of classification techniques for land use/land cover change investigation. Advances in Space Research.50:1250-1265. Srivastava PK, Kiran G, Gupta M, Sharma N, Prasad K. 2012. A Study on Distribution of Heavy Metal Contamination in the Vegetables using GIS and analytical technique. International Journal of Ecology \& Development.21:89-99.

Srivastava PK, Mehta A, Gupta M, Singh SK, Islam T. 2014. Assessing impact of climate change on Mundra mangrove forest ecosystem, Gulf of Kutch, western coast of India: a synergistic evaluation using remote sensing. Theoretical and Applied Climatology.120:685-700.

Srivastava PK, Mukherjee S, Gupta M. 2010. Impact of urbanization on land use/land cover change using remote sensing and GIS: a case study. International Journal of Ecological Economics and Statistics ${ }^{\mathrm{TM}} .18: 106-117$.

Srivastava PK, Mukherjee S, Gupta M, Islam T. 2014. Remote Sensing Applications in Environmental Research: Springer Verlag, ISBN 978-3-319-05905-1.

Strahler AH. 1980. The use of prior probabilities in maximum likelihood classification of remotely sensed data. Remote Sensing of Environment.10:135-163.

Venture EBTJ. 2005. Conserving the Eastern brook trout: An overview of status, threats, and trends. Conservation Strategy Work Group, Eastern Brook Trout Joint Venture, International Association of Fish and Wildlife Agencies Washington, DC. 


\section{List of Figures}

Figure 1 Geographical location of the study area showing Rajaji National Park Figure 2 Flow chart of the methodology used in this study

Figure 3 Unclassified and classified satellite images of the year 1990, 2000 and 2009 respectively Figure 4 Change detection maps of 1990-2000 and 2000-2009.

Figure 5 Biplot diagram of the PCA conducted with landscape metrics of the three dates (BU: built-in; CL: crop land; DF: dense forest; MF: mixed forest; OF: open forest; WB: water body; ---: group of LULC classes; +: 1990; $\square: 2000 ; \bullet:$ 2009; Italic style green letters: landscape metrics) 


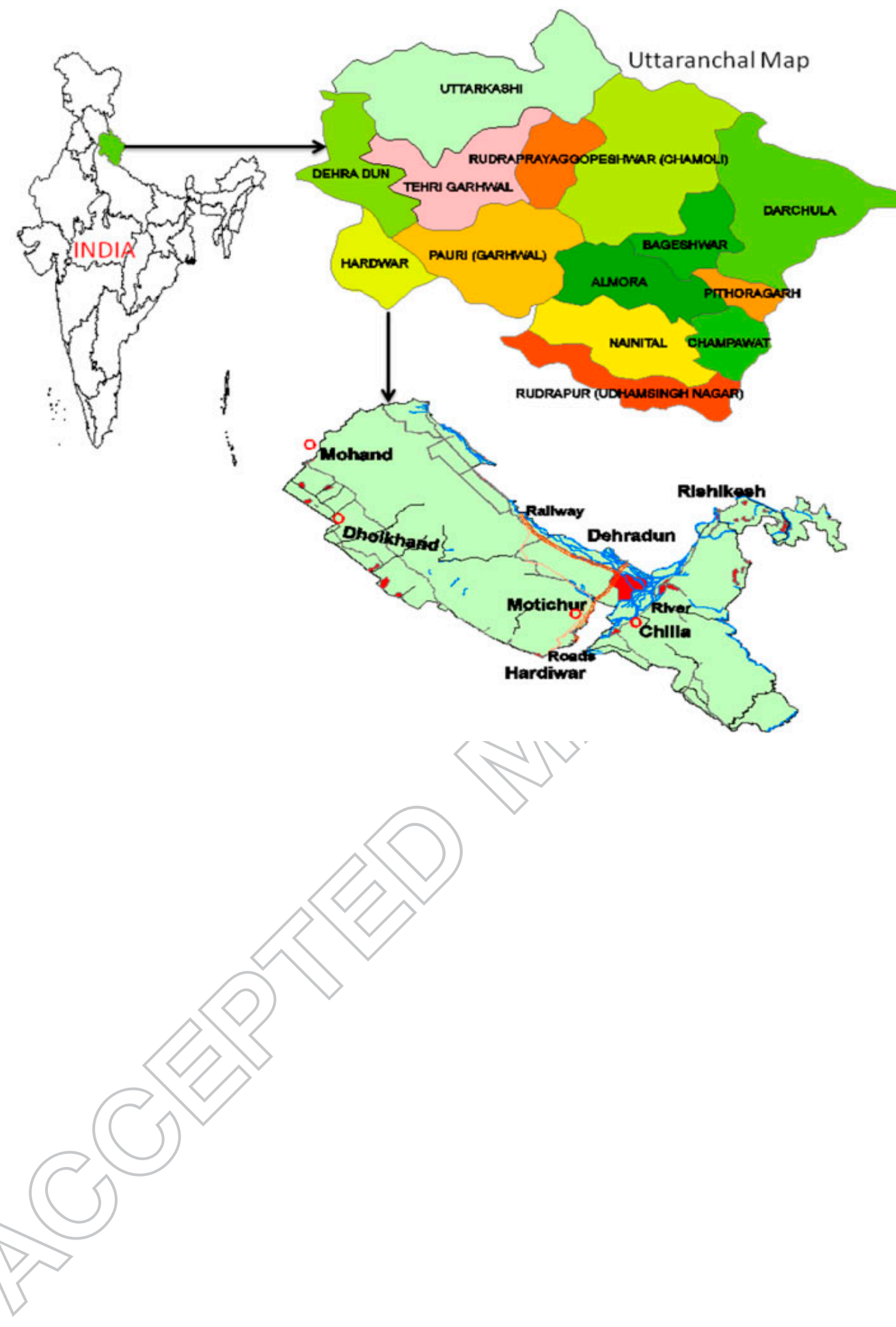




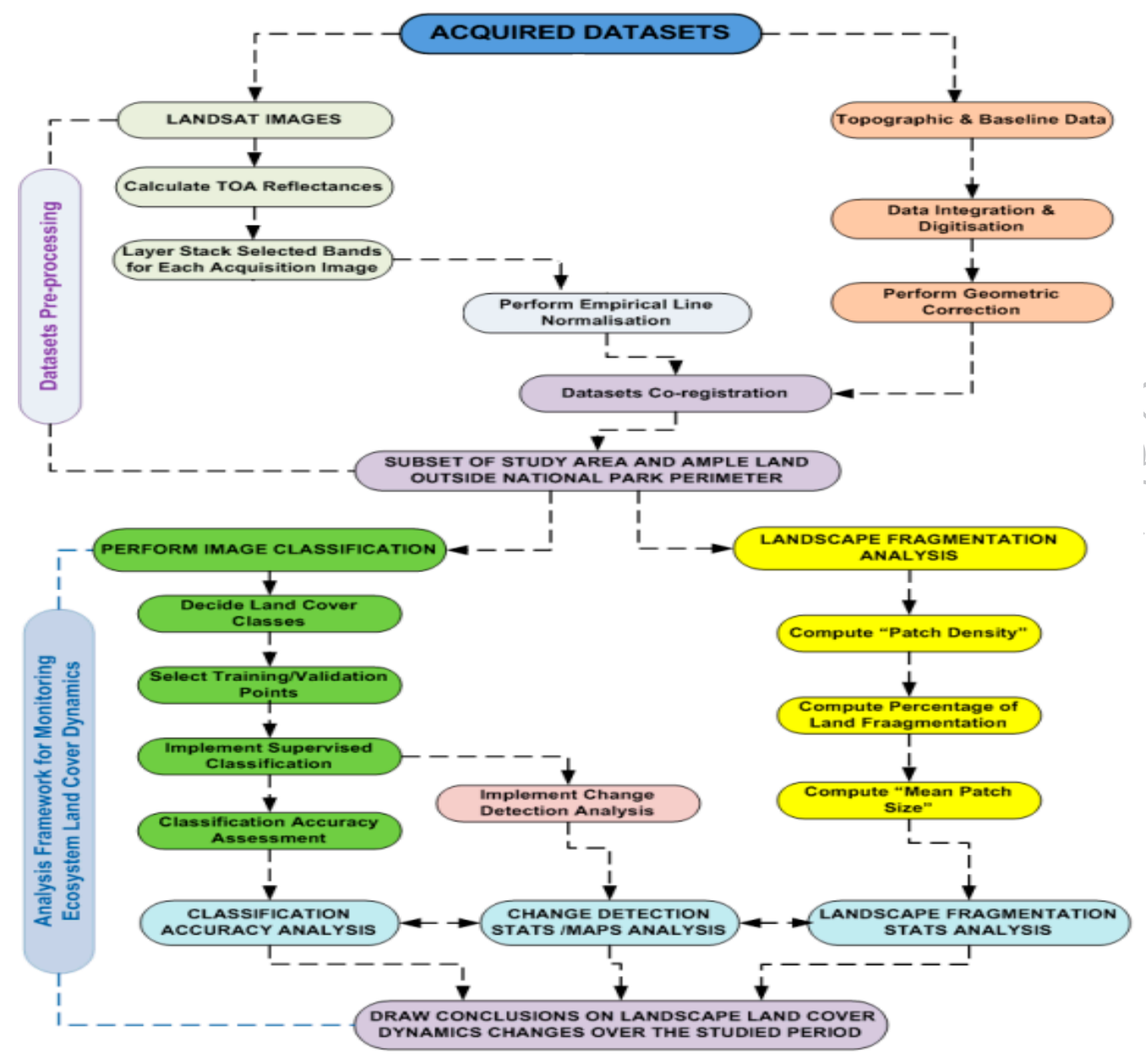



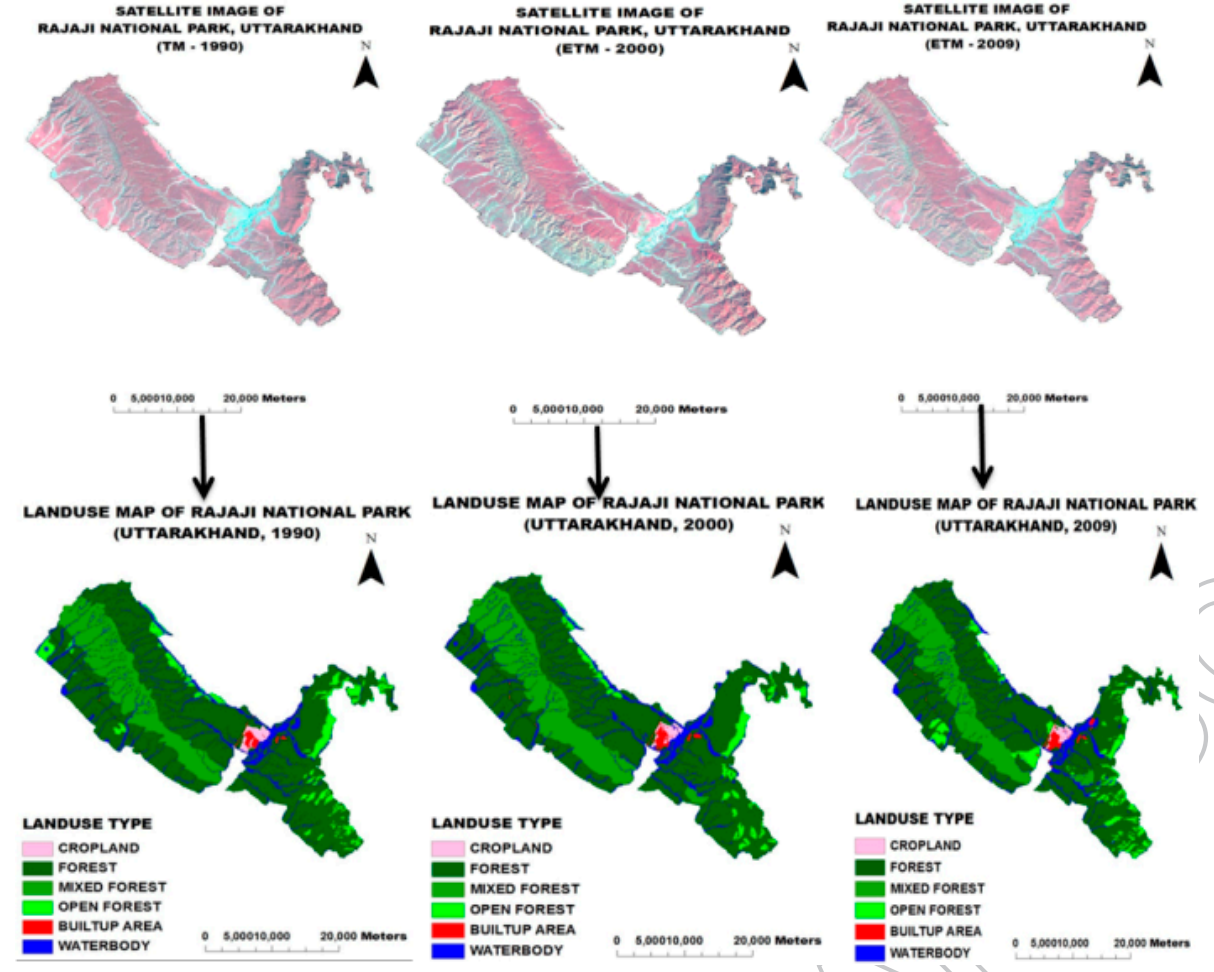
CHANGE DETECTION MAP OF RAJAJI NATIONAL PARK, UTTARAKHAND (1990-2000)

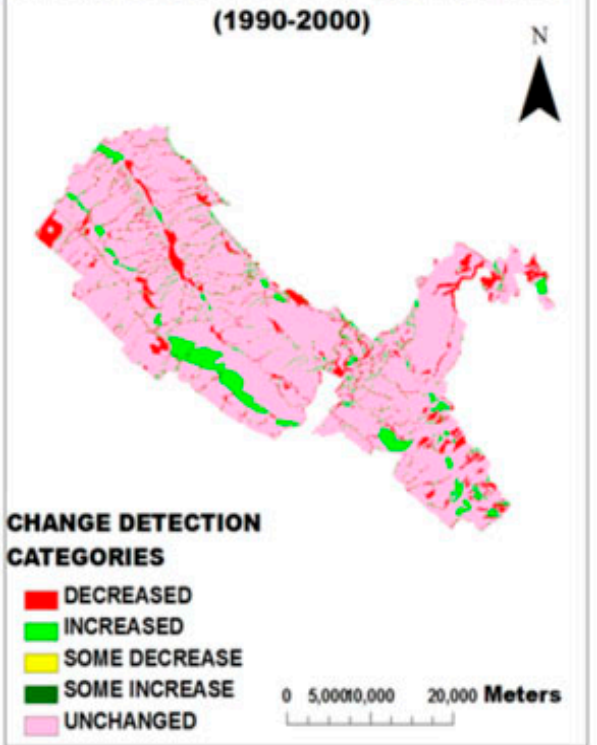

CHANGE DETECTION MAP OF RAJAJI NATIONAL PARK, UTTARAKHAND (2000-2009)

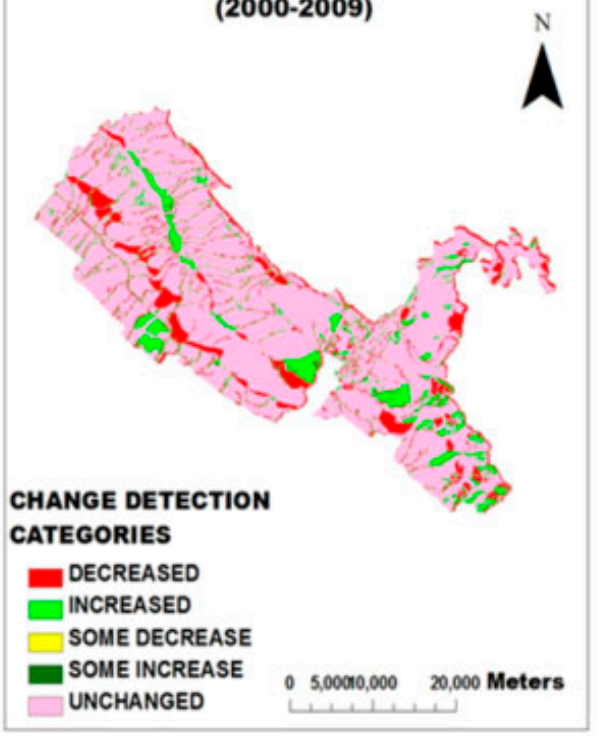




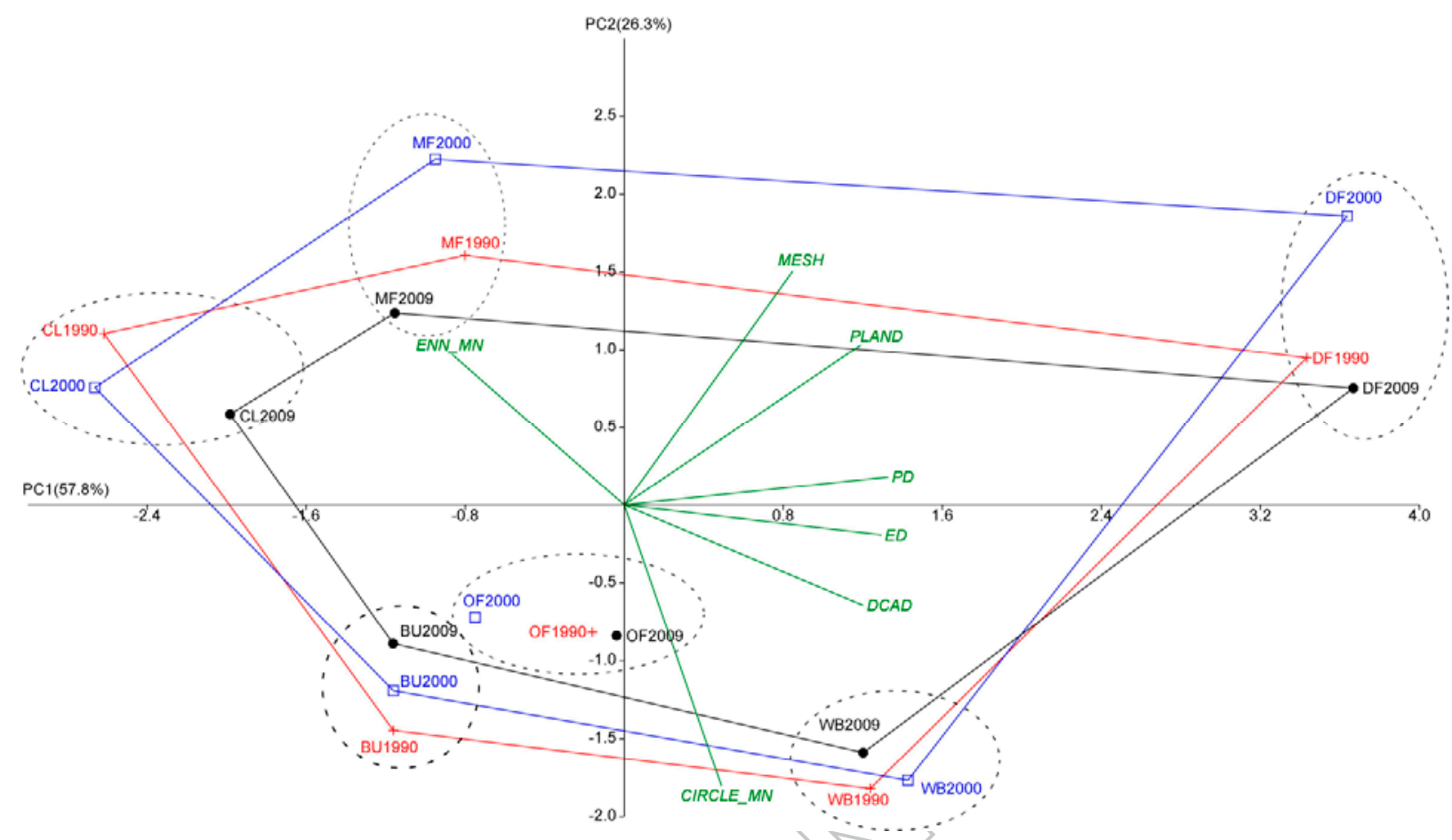




\section{List of Tables}

Table 1: Description of satellite datasets used in this study

Table 2: Classification Accuracy of satellite images

Table 3: Area of different land use classes in $\mathrm{km}^{2}$ for the year 1990-2000-2009

Table 4: Class level landscape metrics (MN: mean of patch level metrics) 
Table 1: Description of Satellite datasets used in this study

\begin{tabular}{|l|l|l|l|l|l|l|}
\hline $\begin{array}{l}\text { S. } \\
\text { No. }\end{array}$ & Sensor Type & Path & $\begin{array}{l}\text { Ro } \\
\text { w }\end{array}$ & $\begin{array}{l}\text { Spatial } \\
\text { Resolution } \\
\text { in meter) }\end{array}$ & $\begin{array}{l}\text { Date of } \\
\text { Acquisition }\end{array}$ & Season \\
\hline 1 & LANDSAT TM & 146 & 39 & 30 & $21 / 10 / 1990$ & Early Winter \\
\hline 2 & LANDSAT ETM+ & 146 & 39 & 30 & $25 / 11 / 2000$ & Early Winter \\
\hline 3 & LANDSAT ETM+ & 146 & 39 & 30 & $23 / 10 / 2009$ & Early Winter \\
\hline
\end{tabular}


Table 2: Classification Accuracy of satellite images

\begin{tabular}{|l|l|l|l|l|l|l|}
\hline \multirow{2}{*}{$\begin{array}{l}\text { Land use/ land } \\
\text { cover classes }\end{array}$} & 2009 & \multicolumn{2}{|l|}{2000} & 1990 & \\
\cline { 2 - 7 } & $\begin{array}{l}\text { Prod. } \\
\text { Acc. }(\%)\end{array}$ & $\begin{array}{l}\text { User } \\
\text { Acc. }(\%)\end{array}$ & $\begin{array}{l}\text { Prod. } \\
\text { Acc. }(\%)\end{array}$ & $\begin{array}{l}\text { User } \\
\text { Acc. }(\%)\end{array}$ & $\begin{array}{l}\text { Prod. } \\
\text { Acc. }(\%)\end{array}$ & $\begin{array}{l}\text { User } \\
\text { Acc. (\%) }\end{array}$ \\
\hline Water bodies & 80.00 & 100.00 & 66.67 & 75.00 & 80.00 & 57.14 \\
\hline Built-up area & 85.71 & 85.71 & 83.33 & 83.33 & 83.33 & 100.00 \\
\hline Crop land & 66.67 & 100.00 & 66.67 & 80.00 & 83.33 & 71.43 \\
\hline Open forest & 83.33 & 71.43 & 83.33 & 83.33 & 80.00 & 100.00 \\
\hline Dense forest & 87.50 & 70.00 & 66.67 & 54.55 & 66.67 & 57.14 \\
\hline Mixed forest & 85.71 & 85.71 & 87.50 & 87.50 & 75.00 & 100.00 \\
\hline $\begin{array}{l}\text { OVERALL } \\
\text { ACCURACY }(\%)\end{array}$ & 82.05 & & 75.00 & & 77.78 & \\
\hline KAPPA COEFF. & 0.78 & & 0.70 & & 0.73 & \\
\hline
\end{tabular}


Table 3: Area of different land use classes in $\mathrm{km}^{2}$ for the year 1990-2000-2009

\begin{tabular}{|l|l|l|l|}
\hline \multirow{2}{*}{ Land use Classes } & \multicolumn{3}{|c|}{ Land use and Land covers (Area in $\mathrm{km}^{2}$ ) } \\
\cline { 2 - 4 } & $\mathbf{1 9 9 0}$ & $\mathbf{2 0 0 0}$ & $\mathbf{2 0 0 9}$ \\
\hline Water bodies & 83.60 & 87.59 & 85.47 \\
\hline Built-up area & 6.50 & 7.85 & 9.35 \\
\hline Dense forest & 568.19 & 562.18 & 550.17 \\
\hline Open forest & 54.44 & 35.74 & 66.02 \\
\hline Mixed forest & 153.95 & 175.03 & 155.24 \\
\hline Crop land & 7.77 & 6.29 & 6.16 \\
\hline Total area & 874.51 & 874.51 & 874.51 \\
\hline
\end{tabular}


Table 4: Class level landscape metrics (MN: mean of patch level metrics)

\begin{tabular}{|c|c|c|c|c|c|c|c|c|c|c|c|c|c|}
\hline $\begin{array}{l}\text { Dat' } \\
\mathrm{e}^{-}\end{array}$ & tType & $\begin{array}{l}\text { PLA } \\
\text { ND }\end{array}$ & $\begin{array}{l}\mathrm{N} \\
\mathrm{P}\end{array}$ & PD & $\begin{array}{l}\mathrm{LP} \\
\mathrm{I}\end{array}$ & $\mathrm{TE}$ & $\begin{array}{l}\text { AREA_ } \\
\text { MN }\end{array}$ & $\begin{array}{l}\text { CIRCLE_ } \\
\text { MN }\end{array}$ & $\begin{array}{l}\text { CORE_ } \\
\text { MN }\end{array}$ & $\begin{array}{l}\mathrm{DC} \\
\mathrm{AD}\end{array}$ & $\begin{array}{l}\text { CAI_ } \\
\text { MN }\end{array}$ & $\begin{array}{l}\mathrm{ENN}_{-} \\
\mathrm{MN}\end{array}$ & $\begin{array}{l}\text { MES } \\
\mathrm{H}\end{array}$ \\
\hline $\begin{array}{l}19 \\
90\end{array}$ & BUILT-UP & 0.26 & 21 & $\begin{array}{l}0.00 \\
85\end{array}$ & $\begin{array}{l}0.1 \\
5\end{array}$ & $\begin{array}{l}11340 \\
0\end{array}$ & 31.0 & 0.88 & 13.5 & $\begin{array}{l}0.00 \\
2\end{array}$ & 6.43 & 217.9 & $\begin{array}{l}0.574 \\
3\end{array}$ \\
\hline $\begin{array}{l}19 \\
90 \\
\end{array}$ & $\begin{array}{l}\text { CROPLAN } \\
\text { D }\end{array}$ & 0.31 & 10 & $\begin{array}{l}0.00 \\
4\end{array}$ & \begin{tabular}{|l|}
0.3 \\
1 \\
\end{tabular} & 39450 & 77.9 & 0.49 & 52.8 & \begin{tabular}{|l|}
0.00 \\
1 \\
\end{tabular} & 6.79 & 3540.6 & $\begin{array}{l}2.437 \\
8 \\
\end{array}$ \\
\hline $\begin{array}{l}19 \\
90\end{array}$ & $\begin{array}{l}\text { DENSE } \\
\text { FOREST }\end{array}$ & 22.87 & $\begin{array}{l}13 \\
4\end{array}$ & $\begin{array}{l}0.05 \\
39\end{array}$ & \begin{tabular}{|l|}
3.8 \\
3 \\
\end{tabular} & $\begin{array}{l}17677 \\
25\end{array}$ & 424.0 & 0.66 & 334.2 & $\begin{array}{l}0.06 \\
6\end{array}$ & 26.95 & 121.2 & $\begin{array}{l}1028 . \\
461\end{array}$ \\
\hline $\begin{array}{l}19 \\
90\end{array}$ & $\begin{array}{l}\text { MIXED } \\
\text { FOREST }\end{array}$ & 6.20 & 31 & $\begin{array}{l}0.01 \\
25\end{array}$ & \begin{tabular}{|l|}
5.5 \\
2 \\
\end{tabular} & $\begin{array}{l}49000 \\
0\end{array}$ & 496.7 & 0.44 & 383.3 & $\begin{array}{l}0.01 \\
0\end{array}$ & 10.82 & 1469.4 & $\begin{array}{l}763.0 \\
326\end{array}$ \\
\hline $\begin{array}{l}19 \\
90 \\
\end{array}$ & \begin{tabular}{|l|} 
OPEN \\
FOREST
\end{tabular} & 2.19 & 64 & $\begin{array}{l}0.02 \\
58\end{array}$ & \begin{tabular}{|l|}
0.5 \\
0 \\
\end{tabular} & \begin{tabular}{|l|}
40340 \\
0
\end{tabular} & 85.1 & 0.69 & 45.7 & $\begin{array}{l}0.03 \\
7\end{array}$ & 29.95 & 281.3 & \begin{tabular}{|l}
9.142 \\
1 \\
\end{tabular} \\
\hline \begin{tabular}{l|}
19 \\
90 \\
\end{tabular} & WATER & 3.36 & 51 & $\begin{array}{l}0.02 \\
05 \\
\end{array}$ & \begin{tabular}{|l|}
1.0 \\
3 \\
\end{tabular} & $\begin{array}{l}17625 \\
75\end{array}$ & 163.9 & 0.88 & 30.7 & $\begin{array}{l}0.07 \\
0<\end{array}$ & 5.65 & 464.3 & $\begin{array}{l}44.58 \\
55 \\
\end{array}$ \\
\hline \begin{tabular}{l|}
20 \\
00
\end{tabular} & BUILT-UP & 0.32 & 25 & $\begin{array}{l}0.01 \\
01\end{array}$ & \begin{tabular}{|l|}
0.1 \\
7 \\
\end{tabular} & $\begin{array}{l}12245 \\
0\end{array}$ & 31.5 & 0.81 & 147 & 20.00 & 6.58 & 141.0 & $\begin{array}{l}0.814 \\
5\end{array}$ \\
\hline $\begin{array}{l}20 \\
00 \\
\end{array}$ & $\begin{array}{l}\text { CROPLAN } \\
\text { D }\end{array}$ & 0.25 & 3 & \begin{tabular}{|l|}
0.00 \\
12 \\
\end{tabular} & $\begin{array}{l}0.2 \\
2 \\
\end{array}$ & 46550 & 210.1 & 0.60 & 110.3 & $\begin{array}{l}0.00 \\
3 \\
\end{array}$ & 34.46 & 4011.5 & $\begin{array}{l}1.198 \\
5 \\
\end{array}$ \\
\hline \begin{tabular}{l|}
20 \\
00
\end{tabular} & \begin{tabular}{|l|} 
DENSE \\
FOREST \\
\end{tabular} & 22.62 & $\begin{array}{l}13 \\
2 \\
\end{array}$ & \begin{tabular}{|l|}
0.05 \\
31 \\
\end{tabular} & & & 425.9 & 0.66 & 338.7 & \begin{tabular}{|l|}
0.05 \\
3 \\
\end{tabular} & 25.87 & 112.7 & $\begin{array}{l}1886 . \\
353\end{array}$ \\
\hline \begin{tabular}{l|}
20 \\
00
\end{tabular} & $\begin{array}{l}\text { MIXED } \\
\text { FOREST }\end{array}$ & 7.04 & 17 & $\begin{array}{l}0.00 \\
68\end{array}$ & $\begin{array}{l}6.8 \\
5\end{array}$ & $\begin{array}{l}42760 \\
0\end{array}$ & 1029.6 & 0.44 & 848.8 & $\begin{array}{l}0.00 \\
4\end{array}$ & 9.54 & 2078.7 & $\begin{array}{l}1168 . \\
493\end{array}$ \\
\hline $\begin{array}{l}20 \\
00\end{array}$ & \begin{tabular}{|l} 
OPEN \\
FOREST
\end{tabular} & 1.44 & 39 & $\begin{array}{l}0.01 \\
57\end{array}$ & $\begin{array}{l}0.3 \\
6 \\
\end{array}$ & $\begin{array}{l}25800 \\
0\end{array}$ & 91.7 & 0.69 & 50.2 & $\begin{array}{l}0.02 \\
5 \\
\end{array}$ & 34.98 & 383.6 & $\begin{array}{l}4.475 \\
8 \\
\end{array}$ \\
\hline \begin{tabular}{l|}
20 \\
00 \\
\end{tabular} & WATER & 3.53 & 55 & $\begin{array}{l}0.02 \\
21\end{array}$ & 1.1 & $\begin{array}{l}16785 \\
25\end{array}$ & 159.3 & 0.85 & 31.7 & $\begin{array}{l}0.08 \\
7\end{array}$ & 6.87 & 517.6 & $\begin{array}{l}48.41 \\
78 \\
\end{array}$ \\
\hline $\begin{array}{l}20 \\
09 \\
\end{array}$ & BUILT-UP & 0.36 & 33 & $\begin{array}{l}0.01 \\
28\end{array}$ & $\begin{array}{l}0.1 \\
7 \\
\end{array}$ & $\begin{array}{l}13210 \\
0\end{array}$ & 28.4 & 0.74 & 12.7 & $\begin{array}{l}0.00 \\
4 \\
\end{array}$ & 8.37 & 243.9 & 0.822 \\
\hline \begin{tabular}{l|}
20 \\
09 \\
\end{tabular} & $\begin{array}{l}\text { CROPLAN } \\
\text { D }\end{array}$ & 0.24 & 12 & $\begin{array}{l}0.00 \\
47\end{array}$ & \begin{tabular}{|l|}
0.1 \\
7 \\
\end{tabular} & 44000 & 51.5 & 0.43 & 29.2 & \begin{tabular}{|l|}
0.00 \\
3 \\
\end{tabular} & 12.71 & 997.6 & $\begin{array}{l}0.833 \\
5 \\
\end{array}$ \\
\hline \begin{tabular}{|l|}
20 \\
09 \\
\end{tabular} & \begin{tabular}{|l|} 
DENSE \\
FOREST
\end{tabular} & 21.39 & 16 & $\begin{array}{l}0.06 \\
49 \\
\end{array}$ & \begin{tabular}{|l|}
3.3 \\
1 \\
\end{tabular} & $\begin{array}{l}19305 \\
50\end{array}$ & 329.5 & 0.66 & 252.5 & $\begin{array}{l}0.06 \\
9 \\
\end{array}$ & 26.53 & 89.9 & $\begin{array}{l}902.6 \\
157 \\
\end{array}$ \\
\hline \begin{tabular}{l|}
20 \\
09
\end{tabular} & $\begin{array}{l}\text { MIXED } \\
\text { FOREST }\end{array}$ & 6.04 & 14 & $\begin{array}{l}0.00 \\
54\end{array}$ & $\begin{array}{l}3.7 \\
9 \\
\end{array}$ & \begin{tabular}{|l|}
42635 \\
0
\end{tabular} & 1108.9 & 0.45 & 890.8 & $\begin{array}{l}0.01 \\
0\end{array}$ & 17.04 & 1417.7 & $\begin{array}{l}475.9 \\
615 \\
\end{array}$ \\
\hline \begin{tabular}{l|}
20 \\
09 \\
\end{tabular} & $\begin{array}{l}\text { OPEN } \\
\text { FOREST }\end{array}$ & 2.16 & 73 & $\begin{array}{l}0.02 \\
84 \\
\end{array}$ & \begin{tabular}{|l|}
0.3 \\
2 \\
\end{tabular} & $\begin{array}{l}45410 \\
0\end{array}$ & 76.3 & 0.70 & 39.0 & $\begin{array}{l}0.04 \\
2 \\
\end{array}$ & 26.60 & 407.6 & \begin{tabular}{|l}
5.665 \\
1 \\
\end{tabular} \\
\hline \begin{tabular}{|l|}
20 \\
09
\end{tabular} & WATER & 3.32 & 70 & $\begin{array}{l}0.02 \\
72\end{array}$ & $\begin{array}{l}1.0 \\
2 \\
\end{array}$ & $\begin{array}{l}17755 \\
50\end{array}$ & 122.1 & 0.85 & 24.6 & $\begin{array}{l}0.06 \\
1\end{array}$ & 5.16 & 495.7 & $\begin{array}{l}35.44 \\
96\end{array}$ \\
\hline
\end{tabular}

